\title{
A Research and Analysis of China's Development of “Outstanding Engineers" Based on Cooperative Education Models
}

\author{
Ma Jiansuo \\ Department of Civil Engineering \\ Hebei University of Architecture \\ Zhangjiakou, China, \\ majs789@sina.com \\ Qu jianping \\ Department of Civil Engineering \\ Hebei University of Architecture \\ Zhangjiakou, China
}

\author{
Bo Peiyu \\ Department of Foreign Languages \\ Hebei University of Architecture \\ Zhangjiakou, China \\ pixie_8608@163.com \\ Yang Qingfeng \\ Department of Architecture and Art \\ Hebei University of Architecture \\ Zhangjiakou, China
}

\begin{abstract}
Through an overview of the university-enterprise cooperative education model and Plan for Educating and Training Outstanding Engineers, this article summarizes the achievements the universities and colleges have obtained and problems encountered with during in practice of "outstanding engineers training plan" in China, discusses how to establish an effective university-enterprise cooperative mechanism according to China's economy and provides some suggestions for schools to implement the plan.
\end{abstract}

Keywords-Outstanding Engineers; cooperative education; vocational education

\section{INTRODUCTION}

The ministry of education proposed a Plan for Educating and Training Outstanding Engineers (PETOE) in 2010 which aims at cultivating and developing a large number of engineering talents and technical personnel with strong creative and practical abilities who are qualified to meet the urgent workforce needs of various industries in China and results in building up an innovative country, industrializing the economic scale and enhancing China's competitiveness and comprehensive national power [1]. The various levels and types of high-skilled engineers developed by Outstanding Engineers Plan would be able to improve the innovation capability of China's technical engineers and meet the needs of the developments of industrialization and modernization for China's economy. China has an enormous population so the engineering education plays a significant role in talents training. However, the current engineering education in China generally has following several problems. First of all, the mode of talents training is single and lacks of diversity and practicality. Next, the capabilities of the engineers graduating from higher education cannot satisfy with the basic recruitment demands of the employees and industries because current engineering education system tends to focuses on teaching all the theories in the classroom as a result the students cannot apply the knowledge for practice. Thirdly, the production, education and researches are not applying with each other while the enterprises are not taking a leading role in training engineers. This article researches on the university-enterprise cooperative education modes aboard during a century period, studies and analyzes on the implementation of "Outstanding Engineer Training Program” in universities and colleges in China, and provides solutions and suggestions to the problems what the program is confronting.

\section{COOPERATIVE EDUCATION}

\section{A. Cooperative Education Definition}

Cooperative education, commonly known as a "co-op", is an educational method combining their fields of study with work experiences in workplaces. On one hand, the students get to apply knowledge learned in the classroom to real world situations. On the other hand, the employers have an opportunity to educate and motivate workers based on the features and needs of positions. Therefore, the firms have an opportunity to recruit the interns with whom they are familiar when the students graduate. It is a win-win situation for both parties. From the beginning of foundation in Cincinnati in 1906, the cooperative education has evolved into talent training programs at the secondary and post-secondary education in various countries.

\section{B. Cooperative education models}

A dual education system of Germany is one of the most successful cooperative education models. Germany's dual vocational education system combines classroom-based learning with hands-on training in the workforce. Learning by doing is a core of the Germany's dual education system. The vocational education system has a history back to the 12th century [2]. Content and training methods are largely jointly formulated by the industry and schools to reflect current 
vocational practice and ensure a bond of theory and practice. Students in Germany complete their high school education between 15 and 18. Approximately 60 percent of them choose to enter a dual training scheme to specialize their fields of careers. Each student needs to approach companies and obtain a trainee position. He spends three or four days a week working at the company and one or two days taking classes at a vocational school. At the company, he learns the professional skills from the fellows. At school, he acquires knowledge relevant to his trade. Students are accountable for both their academic and workplace learning throughout the program. Although the enterprises and schools are independent to each other, students are required to show their grades to their manager. The students take two tests in the middle and final of the program to evaluate their progress [3]. Trainees graduate with a degree of solid knowledge of their trade and practical job experience. The vocational dual system contributes plenty of high quality workforces to Germany's economy every year.

Other models of cooperative education, such as the sandwich model and the American-style semester model have students work 40 hours a week, intensively between 12 weeks and six months [4]. After being apprentice at companies, students return to the classroom to attend courses. Then, they have another internship term.

\section{The negative implication of cooperative education}

Although there are many benefits of cooperative education program, there are some negative implications. A controversial argument is "students tend to fall behind in school work as being taken away from schools and missing a consecutive days of school”. Meanwhile, financial struggle is another challenge. The departments of schools and universities have pressure in funding to maintain the program [5].

\section{THE COOPERATIVE EDUCATION AND “OUTSTANDING ENGINEERS” IN CHINA}

\section{A. The launch of PETOE}

In the early 1980s, cooperative education was introduced to China. After years of active exploration, China has been developing several effective models of cooperative education. In November of 2005, the State Council issued its "Decision to Develop Vocational Education”. The document sets the target to improve the employment rate and promoting vocational education, and consequently creates a skilled workforce to meet enormous market demands of China. In 2010, China's Ministry of Education launched the talent training plan of Outstanding Engineers [8]. The plan proposes an innovative cultivated model for schools and enterprises to cooperate closely in developing skilled engineers which demonstrates the state has started to attach great significance to technical talents. The first batch of universities on the Plan for Educating and Training Outstanding Engineers (PETOE) involves Tsinghua University, Tongji University, Tianjin University, Shanghai Jiaotong University and other 61 schools which choose their backbones of specializations to implement this initiative.

\section{B. Taking Tsinghua University as an example to explain the implementation of PETOE}

As a key university of engineering and technical personnel, Tsinghua University is committed to cultivating engineering talents with abilities of researching, management, innovation and international sights. The strategies of department of Civil Engineering at Tsinghua University to implement the outstanding initiative are formulating a cultivation scheme and curriculum to improve trade's practical ability of students, strengthening cooperation with first-class universities and wellknown enterprises domestic and abroad and improving students' international sights, innovation ability, team work, writing and communication skills. First of all, the department of Civil Engineering intends to improve students' comprehensive abilities through modification of training scheme and curriculum. On the basis of public basic course system, the training scheme is added English, Chinese, mathematics and other subjects. Meanwhile, the professional training plan is modified to increase some challenging normal courses. With series of measures, the reform has achieved initial results which are manifested in improving a scientific nature of training scheme, increasing the interaction between instructors and students and strengthening the comprehensive abilities of engineering students. Secondly, through the establishment and operation of some priority projects of cooperation with top universities and well-known firms worldwide, such as "Tsinghua-Berkeley global entrepreneurship program", the "international master's degree" and "experimental class engineering physics", the engineering students of Tsinghua University have enhanced their international vision and team work skill, and strengthened their capabilities of learning professional knowledge and innovation [6].

\section{SOME SUGGESTIONS FOR SCHOOLS TO CARRY OUT PETOE}

Through deeply researches and analysis on the positive exploration of various colleges and universities in China, this paper summarizes some feasible measures and suggestions for schools to develop outstanding engineers according to the initiative PETOE. Firstly, the undergraduates are requested to complete their degree under a " $3+1$ " year mode which is engineering students spend three years on taking classes at school and one year taking internship in companies [7]. A student finds a company to complete his cooperative education program through different learning courses, such as, cognition practice, production practice, academic subject, professional experiment and graduation project. Secondly, colleges and universities accept and separate students through two methods: college entrance admission and mutual selection in school. Through the college entrance admission, schools are able to choose students who are clever in science and engineering. On the other hand, mutual selection requires students after one year of study at school to apply through taking written exams and interviews by universities and enterprises. Enterprises are welcome to participate in designing the training scheme, interviewing the students and determining on the admissions. The tuition fee of the outstanding engineers program is paid by the enterprises and the candidates in proportion. The student 
can make his own decision whether to enter to the company or not when graduation. Finally, it is essential for the outstanding engineers plan to build a sophisticated teaching team to guide and instruct the future engineers. It is a common problem that majority post-secondary schools lack of experienced teachers to teach not only classroom principles but also practical application. To solve it, the schools ought to set policies and offer financial support to encourage lecturers to gather work experience and obtain frontier information of markets and industries. At the same time, schools are responsible to recruit and engage engineers and managers from enterprises as guest lecturers or instructors to involve in teaching professional courses and advising graduation projects.

\section{CONCLUSION}

All in all, to implement the Plan for Education and Training Outstanding Engineers and reinforce the cultivation of technical and engineering talents, the colleges and universities are required to take initiatives to design the cultivating objects, formulate the cultivating scheme and take effective steps to make the students more valuable to an employer upon graduation based on the researches on the successful models worldwide and analysis of market demands and the specializations of each school.

\section{REFERENCES}

[1] "A Plan for Educating and Training Outstanding Engineers (PETOE)." Ministry of Education. January 8, 2011. http://www.moe.gov.cn/publicfiles/business/htmlfiles/moe/s3860/20110 2/115066.html.

[2] "Germany’s Dual System of vocational education and training." worldskillsleipzig. 2013.

http://www.worldskillsleipzig2013.com/en/education/germany_dual_sys tem/.

[3] Carroll, Caitlan. Young Germany. July 18, 2013. http://www.younggermany.de/topic/study/courses-degrees/germanys-dual-vocationaleducation-system.

[4] McCallum, B.A. "'"They Said It Wouldn't Work (A History of Cooperative Education in Canada)." Cooperative Education \& Internship Association., January 1, 1988.

[5] Haddara, Skanes, Mahmoud, Heather . "'A reflection on cooperative education: from experience to experiential learning"." Asia-Pacific Journal of Co-operative Education, June 18, 2007.

[6] "A Training Scheme of Trial Specializations of Civil Engineering at Tsinghua University." 2010.

[7] Yang, C. "A Tentative Exploration of the Educational Training Mechanism of Outstanding Engineers Miner Processing Engineering Major." International Conference on Social Science, Education Managemnet and Sports Educaiton, 2015: 44-47.

[8] Ministry of Education on P.R. China. June 13, 2010. http://www.moe.edu.cn/publicfiles/business/htmlfiles/moe/s3860/20101 0/109630.html. 